\title{
PENINGKATAN KETERAMPILAN BERKOMUNIKASI ANAK SD MENGGUNAKAN MODEL THINK PAIR SHARE BERBANTUAN MEDIA ULAR TANGGA
}

\author{
Dwi Ratna Khoirun $\mathrm{Naza}^{1}$, Nur Fajrie ${ }^{2}$, Sri Utaminingsih ${ }^{3}$,
}

Universitas Muria Kudus/ Pendidikan Guru Sekolah Dasar

Email: ${ }^{1}$ ratnaa.naza@gmail.com

\begin{tabular}{|c|c|}
\hline Info Artikel & Abstract \\
\hline $\begin{array}{l}\text { Sejarah Artikel: } \\
\text { Diterima : 18-08-2021 } \\
\text { Direvisi : 03-11-2021 } \\
\text { Disetujui : } 25-11-2021\end{array}$ & $\begin{array}{l}\text { This study aims to improve the communication skills of fourth grade students in the village } \\
\text { of Sinanggul by applying the Think Pair Share model with the help of snakes and ladders } \\
\text { media. This participatory action research was carried out in the homes of fourth grade } \\
\text { elementary school children in the village of Sinanggul with } 4 \text { children as research subjects, } \\
\text { this research lasted for two cycles, each cycle consisting of four stages, namely planning, }\end{array}$ \\
\hline $\begin{array}{l}\text { Keywords: } \\
\text { Communication Skills, Think } \\
\text { Pair Share }\end{array}$ & $\begin{array}{l}\text { study is the Think Pair Share learning model assisted by the snake and ladder media, while } \\
\text { the dependent variable is the communication skills of fourth grade elementary school } \\
\text { children in the village of Sinanggul. Data collection techniques using test techniques, }\end{array}$ \\
\hline & $\begin{array}{l}\text { were analyzed quantitatively and qualitatively. The results showed that (1) there was an } \\
\text { increase in student learning activities in the application of the assisted Think Pair Share } \\
\text { model, there was an increase from } 0 \% \text { to } 50 \% \text { in cycles } 1 \text { and } 2,(2) \text { the communication } \\
\text { skills of students increased after being given action, this is evidenced by students who dare } \\
\text { to express their opinions in public. }\end{array}$ \\
\hline
\end{tabular}

\begin{abstract}
Abstrak
Penelitian ini bertujuan untuk meningkatkan keterampilan berkomunikasi siswa kelas IV di desa Sinanggul dengan menerapkan model Think Pair Share berbantuan media ular tangga. Penelitian tindakan partisipatif ini dilaksanakan di rumah anak kelas IV SD di desa Sinanggul dengan subjek penelitian 4 anak, penelitian ini berlangsung selama dua siklus, setiap siklus terdiri dari empat tahap yaitu perencanaan, tindakan, pelaksanaan, dan pengamatan serta refleksi. Variabel bebas dalam penelitian ini adalah model pembelajaran Think Pair Share berbantuan media ular tangga, Sedangkan variabel terikat adalah keterampilan berkomunikasi anak kelas IV SD di desa Sinanggul. Teknik pengumpulan data menggunakan teknik tes, wawancara, observasi, dokumentasi. Data yang telah diperoleh dari tindakan dianalisis secara kuantitatif dan kualitatif. Hasil penelitian menunjukkan bahwa (1) terdapat peningkatan aktivitas belajar siswa dalam penerapan model Think Pair Share berbantuan terdapat peningkatan dari $0 \%$ menjadi $50 \%$ pada siklus 1 dan 2 , (2) keterampilan berkomunikasi yang dimiliki siswa meningkat setelah diberikan tindakan, hal ini dibuktikann dengan siswa yang berani mengutarakan pendapatnya di depan umum.
\end{abstract}

(C) 2021 Universitas Muria Kudus 
Dwi Ratna Khoirun Naza, Nur Fajrie, Sri Utaminingsih

Peningkatan Keterampilan Berkomunikasi Anak SD Menggunakan Model Think Pair Share........... Jurnal Prasati Ilmu. Volume 1 Nomor 3 Hlm 28-35

\section{PENDAHULUAN}

Pendidikan pada saat ini memegang peranan yang sangat penting dalam kehidupan manusia. Hal ini karena pendidikan dapat mempengaruhi segala aspek kepribadian maupun kehidupan seseorang, dan juga menentukan kemajuan suatu bangsa. Di Indonesia sendiri upaya peningkatan mutu pendidikan dilakukan dari tahun ke tahun oleh pemerintah. Salah satunya dengan memperbaiki kurikulum yang digunakan di sekolah. Saat ini kurikulum nasional yang digunakan adalah kurikulum 2013. Seperti halnya di SD/MI sederajat kurikulum 2013 dengan desain pembelajaran tematik.

Pembelajaran tematik merupakan pendekatan pembelajaran yang memadukan berbagai kompetensi dari berbagai mata pelajaran ke dalam berbagai tema. Pada pembelajaran tematik terpadu aspek yang ditekankan adalah pengembangan potensi individu masing-masing dan belajar berdasarkan pengalaman. Dalam pelaksanaannya, pembelajaran tematik ini juga mengalami beberapa kendala, antara lain kemampuan guru menyampaikan pelajaran, media pembelajaran dan kemampuan siswa dalam menerima pembelajaran. Observasi yang dilaksanakan pada hari Senin, 15 Februari 2021 di desa Sinanggul lingkungan RT 14 RW 03 pada siswa kelas IV ditemukan adanya permasalahan yang cukup menarik, yaitu keterampilan komunikasi siswa yang rendah. Dalam pembelajaran tematik yang berorientasi pada keaktifan siswa, keterampilan komunikasi siswa masih sangat kurang.

Berdasarkan wawancara dengan guru kelas IV SD Sinanggul 04 yang telah dilakukan pada bulan Maret tahun 2021, ditemukan permasalahan dalam pembelajaran IPS dan Bahasa Indonesia yang menarik perhatian penulis, yaitu keterampilan komunikasi. Selain masalah model dan media pembelajaran kenyataannya keterampilan komunikasi oleh siswa terkadang kurang menjadi perhatian guru. Padahal Salah satu indikator pembelajaran tematik yang baik adalah jika siswa dapat berkomunikasi dengan baik. Kurang berhasilnya pembelajaran tematik didukung dengan hasil belajar peserta didik yang kurang memuaskan dalam beberapa mata pelajaran. Peserta didik yang belum tuntas sebanyak 52\% dengan KKM 72. Hal tersebut tentu saja dipengaruhi banyak faktor. Seperti yang sudah dijelaskan diatas bahwa siswa yang pintar cenderung aktif sendiri dibandingkan siswa yang lain. Hal ini karena siswa yang lain tidak merasa percaya diri dengan pendapat yang dimiliki atau apabila terdapat hal hal yang ingin ditanyakan dan berkaitan dengan materi siswa kurang berani. Dengan demikian keterampilan komunikasi yang dimiliki siswa juga masih sangat rendah.

Upaya yang dapat dilakukan untuk mengatasi masalah-masalah di atas adalah dengan menerapkan model pembelajaran yang menuntut siswa lebih aktif dalam segala hal, termasuk komunikasi. (Nikmah, Rahayu, dan Fajrie, 2020) menyebutkan pemilihan model pembelajaran dapat mendorong siswa untuk terlibat aktif dalam pembelajaran. Salah satu model pembelajaran yang bisa digunakan adalah Model Pembelajaran Kooperatif Tipe Think Pair Share (TPS). Model kooperatif tipe Think Pair Share merupakan model pembelajaran yang memiliki prosedur yang ditetapkan secara eksplisit untuk memberi siswa waktu lebih banyak berpikir, menjawab, dan saling membantu satu sama lain. Melalui penerapan model Think Pair Share siswa dapat berinteraksi selama pembelajaran berlangsung (Saidah, 2015).

Sesuai dengan pendapat Monica \& Sahetapi (2019) dalam penelitiannya yang berjudul, "Penerapan Metode Think Pair Share Untuk Meningkatkan Kerja Sama Siswa Kelas VII pada Mata Pelajaran IPA Terpadu." Metode Think Pair Share yang diterapkan dikelas mampu meningkatkan kerja sama siswa kelas VII pada mata pelajaran IPA Terpadu di SLH Way Pengubuan Lampung. Hal ini terlihat melalui perubahan yang terjadi selama empat kali tatap muka pembelajaran yang dilakukan menggunakan metode Think Pair Share. Hasil angket self-evaluation menunjukkan kriteria sangat baik untuk indikator pertama (100\%), indikator kedua (100\%), indikator ketiga $(88,89 \%)$ dan indikator keempat (100\%). Selanjutnya menunjukkan kriteria baik untuk indikator kelima $(66,67 \%)$. Hasil angket peerevaluation menunjukkan kriteria sangat baik untuk indikator pertama $(94,44 \%)$, indikator kedua $(88,89 \%)$ dan indikator keempat $(94,44 \%)$. Selanjutnya menunjukkan kriteria baik untuk indikator ketiga $(77,78 \%)$ dan indikator kelima $(66,67 \%)$.

Hal tersebut sejalan dengan pendapat Arends (dalam Trianto, 2010: 81) menyatakan bahwa model kooperatif tipe Think Pair Share merupakan suatu cara yang efektif untuk membuat variasi suasana pola diskusi kelas, dengan asumsi bahwa diskusi membutuhkan pengaturan untuk mengendalikan kelas secara keseluruhan, dan prosedur yang digunakan dalam model koopertif tipe Think Pair Share dapat 
Dwi Ratna Khoirun Naza, Nur Fajrie, Sri Utaminingsih

Peningkatan Keterampilan Berkomunikasi Anak SD Menggunakan Model Think Pair Share........... Jurnal Prasati Ilmu. Volume 1 Nomor 3 Hlm 28-35

memberi lebih banyak waktu peserta didik untuk berpikir, merespon dan saling membantu.

Penelitian lain oleh Supomo (2018) yang berjudul, "Pengaruh Model Think-Pair-Share (TPS) Untuk Meningkatkan Motivasi Belajar Siswa Dalam Pembelajaran Pendidikan Kewarganegaraan di Kelas VII SMP Kartika IV 8 Malang Tahun Pelajaran 2017/2018." Pelaksanaan peningkatan motivasi siswa Kelas VII SMP Kartika IV 8 Malang Tahun Pelajaran 2017/2018 pada siklus I aktivitas siswa belum menampakkan keseriusan baik kegiatan kelompok maupun pada kegiatan presentasi kelas. Sedangkan pada siklus II terjadi peningkatan aktivitas siswa, terlihat pada keaktifan siswa bertanya dan merespons pertanyaan. Penlitian terkait model Think Pair Share juga dilakukan oleh Nurazizah dan Wuryandari (2019) dengan judul "Pengaruh model kooperatif tipe Think Pair Share terhadap kerja sama siswa." Hasil penelitian menunjukkan bahwa terdapat pengaruh yang positif dan signifikan model Think Pair Share terhadap kerja sama siswa kelas IV Sekolah Dasar dibuktikan dengan nilai t sebesar 4,014 dan p 0,000<0,05.

Pembelajaran dengan model kooperatif tipe Think Pair Share dengan pembelajaran konvensional memberikan dampak yang berbeda pada kemampuan kerja sama siswa. Hal tersebut terbukti dari hasil yang diperoleh pada kelas eksperimen dan kelas kontrol, kerja sama siswa pada kelas eksperimen lebih tinggi dibandingkan dengan kelas kontrol. Sehingga dapat dikatakan bahwa kerja sama pada kelas eksperimen lebih baik dibandingkan dengan kelas kontrol. Dengan demikian dapat diketahui bahwa model kooperatif tipe Think Pair Share berpengaruh terhadap kerja sama siswa.

Berdasarkan uraian tersebut penerapan model pembelajaran kooperatif Think Pair Share sebagai salah satu model pembelajaran yang dapat meningkatkan kemampuan berpikir, menjawab dan saling membantu sama lain ( Soimin, 2014: 208). Untuk mengarahkan model pembelajaran agar menarik dan dapat meningkatkan kemampuan siswa salah satu media yang digunakan adalah ular tangga. Sehingga peneliti akan melakukan penelitian dengan judul "Peningkatan Keterampilan Berkomunikasi Menggunakan Model Think Pair Share Berbantuan Media Ular Tangga" untuk kelas IV SD di lingkungan RT 14 RW 03 desa Sinanggul Jepara.

\section{METODE PENELITIAN}

Penelitian ini dilaksanakan di desa Sinanggul RT 14 RW 03 Kecamatan Mlonggo Kabupaten Jepara. Narasumber dalam penelitian ini adalah 4 orang siswa yang berasal dari SD N Sinanggul 04 Mlonggo Jepara. Penelitian ini menggunakan model mixed methods. Menurut Creswell (2007: 5) mixed methods adalah penelitian yang mengumpulkan dan menganalisis data dengan mencampurkan data kualitatif dan kuantitatif. Dengan demikian dalam penelitian ini menggunakan dua paradigma yang dijadikan pedoman dalam pengumpulan dan analisis data. Penelitian ini menggunakan strategi metode campuran sekunsial/bertahap eksplanatoris. Strategi ini menggabungkan data yang ditemukan dari satu metode ke metode lainnya. Strategi ini dapat dilakukan dengan interview terlebih dahulu untuk mendapatkan data kualitatif lalu diikuti dengan data kuantitatif melalui angket/ survey.

Tahapan awal strategi ini adalah mengumpulkan dan menganalisis data kuantitatif kemudian diikuti oleh pengumpulan dan menganalisis data kualitatif yang dibangun berdasarkan hasil awal kuantitatif. Bobot utama adalah data kuantitatif. Sebagai sebuah metode penelitian, mixed methods berfokus pada pengumpulan, penganalisisan, dan pencampuran data kuantitatif dan kualitatif dalam suatu penelitian tunggal atau lanjutan. Penggunaan metode kualitatif dan kuantitatif dalam satu penelitian dapat memberikan pemahaman atau jawaban dari masalah penelitian secara lebih dibandingkan dengan penggunaan salah satunya.

Alur dalam penelitian menggunakan siklus penelitian tindakan sebagaimana berikut: 1) Perencanaan, peneliti menentukan fokus penelitian, perencanaan model pembelajaran, RPP, identifikasi masalah, 2) Pelaksanaan Tindakan, peneliti melakukan penerapan model Think Pare Share dalam kegiatan pembelajaran, 3) Obervasi, peneliti melakukan pengamatan langsung teradap proses pembelajaran, dan 4) Analisis dan Refeleksi, peneliti melakukan analisis terhadap hasil pembelajaran model Think Pare Share yang diterapkan.

Penelitian ini mengumpulkan data dengan cara tes, observasi, wawancara, dan dokumentasi terhadap data yang diperlukan. Selain itu, peneliti juga melakukan evaluasi berupa soal tes dan non tulis kepada peserta didik. Hal ini dilakukan untuk mengetahui seberapa efektif model Think Pare Share dan media ular tangga dapat meningkatkan keterampilan berkomunikasi siswa. 
Dwi Ratna Khoirun Naza, Nur Fajrie, Sri Utaminingsih

Peningkatan Keterampilan Berkomunikasi Anak SD Menggunakan Model Think Pair Share........... Jurnal Prasati Ilmu. Volume 1 Nomor 3 Hlm 28-35

Indikator keberhasilan dalam penelitian ini adalah 1) Siswa menjadi lebih aktif dalam proses pembelajaran, 2) Suasana pembelajaran menjadi lebih menyenangkan dan menarik bagi siswa, dan 3) Siswa menjadi lebih fokus dan perhatian selama proses pembelajaran. Tercapainya indikator tersebut dengan menunjukkan nilai yang memenuhi KKM 75 dan dikatakan tuntas.

\section{HASIL DAN PEMBAHASAN \\ Keterampilan Berkomunikasi}

Keterampilan atau skill adalah

kemampuan untuk mengoperasikan pekerjaan secara mudah dan cermat (Widiastuti, 2010: 49). Keterampilan adalah kemampuan menggunakan akal, fikiran, ide dan kreatifitas dalam mnegerjakan, mengubah ataupun membuat sesuatu menjadi lebih bermakna sehingga menghasilkan nilai dan hasil dari sesuatu tersebut (Suprapto, 2009: 135) Dengan demikian dapat diambil kesimpulan bahwa keterampilan adalah kemampuan yang dimiliki seseorang untuk mengerjakan sesuatu secara efektif dan menghasilkan nilai. Keterampilan dapat terbagi menjadi dua, yaitu keterampilan phylogenetic dan ontogenetic. Keterampilan phylogenetic adalah keterampilan yang dibawa sejak lahir dan dapat berkembang sesuai usia anak. Sedangkan keterampilan ontogenetic adalah keterampilan yang dihasilkan dari latihan dan pengalaman sebagai hasil dari pengaruh lingkungan (Amrullah, 2003: 18). Oleh karena itu, untuk mencapai suatu keterampilan yang baik perlu memperhatikan hal-hal seperti kemauan serta keseriusan dalam individu dan motivasi dalam menguasai keterampilan tersebut. Selain itu proses belajar mengajar yang sesuai dengan potensi serta latihan atau praktek yang sering dilakukan (Amirullah, 2003: 18).

Komunikasi menurut Suprapto (2011: 6) adalah suatu proses interaksi yang mempunyai arti sesama manusia. Komunikasi merupakan suatu proses dimana komponen komponennya saling terkait, dan bahwa komunikatornya beraksi dan beraksi sebagai suatu kesatuan dan keseluruhan. Komunikasi yang dilakukan manusia itu menggunakan alat penghubung berupa lambang-lambang dalam bentuk bahasa lisan, tulisan, bahasa tubuh dan lain-lainnya, sehingga pesan mudah dimengerti dan dipahami oleh penerima pesan. Komunikasi dapat dimaknai sebagai proses seseorang maupun kelompok orang menciptakan serta menggunakan sejumlah informasi agar saling terhubung dengan lingkungan sekitar.
Komunikasi merupakan proses sosial yang erat kaitannya dengan aktivitas manusia serta sarat akan pesan maupun perilaku. keterampilan berkomunikasi adalah proses interaksi kegiatan manusia yang terdiri atas dua orang atau lebih yang saling memengaruhi dan bertukar informasi, pengetahuan, pikiran agar dapat menggugah partisipasi satu sama lain, sehingga informasi yang diberitahukan tersebut menjadi milik bersama. Adapun tujuan komunikasi menurut Rumono, Setyabudi, dan Pradekso (2014) adalah untuk membangun atau menciptakanpemahaman atau pengertian bersama. Saling memahami dan mengerti bukan berartiharus menyetujui tapi mungkin dengan komunikasi terjadi suatu perubahan sikap,pendapat, perilaku atau perubahan secara sosial.

\section{Think Pair Share}

Model Think Pair Share atau berpikir, berpasangan, berbagi merupakan model struktural dalam pembelajaran kooperatif yang dirancang untuk mempengaruhi pola interaksi siswa. Model ini dikembangkan pertama kali oleh Frang Lyman dan koleganya di Universitas Maryland dari penelitianbelajar kooperatif dan waktu tunggu. Frang Lyman dalam Huda (2013:206), menyatakan bahwa model pembelajaran Think Pair Share merupakan suatu cara efektif untuk membuat variasi suasana pola diskusi kelas, dengan asumsi bahwa semua diskusi membutuhkan pengaturan untuk mengendalikan kelas secara keseluruhan, dan prosedur yang digunakan.

Menurut Trianto (2007:61-62) sintaks dalam pembelajaran Think Pair Share, yaitu: berpikir (think), berpasangan (pair), dan berbagi (share). Dalam pembelajaran tematik, menurut Huda (2013: 207) langkah-langkah model pembelajaran cooperative learning tipe think pair share dalam pelaksanaan pembelajaran adalah sebagai berikut: (1) Siswa ditempatkan dalam kelompok-kelompok. Setiap kelompok terdiri dari empat anggota/siswa, (2) Guru memberikan tugas pada setiap kelompok (3) Masing-masing anggota memikirkan dan mengerjakan tugas tersebut sendiri-sendiri terlebih dahulu, (4) Kelompok membentuk anggota-anggota secara berpasangan. Setiap pasangan mendiskusikan hasil pengerjaan individunya. (5) Kedua pasangan lalu bertemu kembali dalam kelompoknya masing-masing untuk membagikan hasil diskusinya.

\section{Media Permainan Ular Tangga}

Kata media berasal dari bahasa Latin medius yang secara harfiah memiliki arti tengah, 
Dwi Ratna Khoirun Naza, Nur Fajrie, Sri Utaminingsih

Peningkatan Keterampilan Berkomunikasi Anak SD Menggunakan Model Think Pair Share........... Jurnal Prasati Ilmu. Volume 1 Nomor 3 Hlm 28-35

perantara atau pengantar (Arsyad, 2013: 3). Dalam konteks pendidikan, media biasa disebut dengan fasilitas pembelajaran, yang membawa pesan kepada pembelajar. Jadi media dapat diartikan sebagai perantara yang mengantar informasi dari sumber belajar ke peserta didik agar peserta didik menjadi lebih paham, aktif, kreatif dan bersemangat. Media pembelajaran memiliki beberapa fungsi dan manfaat yaitu: (1) dapat memperjelas penyajian pe-san dan informasi sehingga dapat mening-katkan proses dan hasil belajar, (2) dapat meningkatkan dan mengarahkan perhatian anak sehingga dapat menimbulkan motiva-si belajar, (3) dapat mengatasi keterbatasan indera, ruang dan waktu, (4) dapat mem-berikan kesamaan pengalaman kepada sis-wa, (5) pembelajaran akan lebih menarik, (6) siswa lebih banyak melakukan kegiatan belajar, sebab tidak hanya mendengarkan uraian guru, tetapi juga aktivitas lain seperti mengamati, melakukan, mendemonstrasikan dan lain-lain dan (7) metode mengajar akan lebih bervariasi, tidak se-matamata komunikasi verbal melalui pe-nuturan katakata oleh guru, sehingga siswa tidak bosan. Isnarto, Abdurrrahman, dan Sugianto (2017)

Menurut Susanto (2009: 19), game menurut istilah berarti permainan. Dalam kegiatan mentoring, games biasanya berfungsi sebagai warning up (pemanasan), penghilang kejenuhan dalam materi yang melelahkan, mendukung peserta mentoring agar lebih aktif dan memberi respons, serta masih banyak lagi fungsi strategis sebuah games sekalipun bentuknya amat sederhana. Game memberikan peluang terhadap pembelajar untuk mengembangkan keterampilan, pengetahuan dan sikap melalui prinsip dan fitur yang digunakan di dalam game play Setiawan, Praherdiono, dan Sulthoni (2019). Selanjutnya (Fardani, 2021) menyebutkan bahwa melalui bermain, anak akan lebih mudah mempelajari banyak hal. Setiap permainan ular tangga untuk media pembelajaran juga harus disesuaikan dengan materi yang dipelajari agar siswa lebih aktif dan termotivasi dalam belajar. Ular tangga adalah permainan papan untuk anak-anakyang dimainkan oleh dua orang atau lebih. Di dalam papan permainan terdapat kotak-kotak kecil dan dibeberapa kotak terdapat sejumlah tangga dan ular yang menghubungkan dengan kotak lain. Permainan ini dapat digunakan untuk semua mata pelajaran dan semua jenjang kelas, karena siswa hanya menjawab berbagai pertanyaan melalui permainan tersebut. Permainan ini dapat dimainkan untuk semua mata pelajaran dan semua jenjang kelas, karena didalamnya hanya berisi berbagai bentuk pertanyaan yang harus dijawab oleh siswa melalui permainan tersebut sesuai dengan jenjang kelas dan mata pelajaran tertentu.

\section{Pra Penelitian Tindakan Kelas ( Masa Pandemi Covid-19)}

Penelitian tindakan partisipatif ini dilaksanakan di masa pandemi Covid-19. Penelitian telah disesuaikan dengan masa pandemi yang mengharuskan siswa untuk belajar di rumah secara daring. Melihat kondisi tersebut peneliti memutuskan untuk melakukan penelitian di lingkungan desa peneliti, tepatnya di Desa Sinanggul, Mlonggo kabupaten Jepara. Di lingkungan RT 14 RW 03 rata rata bersekolah di SDN 4 Sinanggul dengan jumlah siswa 14 orang. Dengan demikian peneliti memilih 4 responden yang terdiri dari 4 siswa putra.

Berdasarkan hasil analisis prasiklus yang dilakukan oleh peneliti menunjukkan bahwa keterampilan berkomunikasi siswa kelas IV SD di lingkungan tersebut masih belum maksimal. Hasil wawancara dengan guru kelas IV menunjukkan bahwa dalam mengajar guru masih banyak menggunakan metode ceramah, serta hanya sesekali menggunakan model dan media pembelajaran yaitu pada materi tertentu saja. Guru juga kurang memberikan inovasi pembelajaran kepada siswa. Data prasiklus didukung dengan nilai hasil PTS 6 Responden dengan 4 responden masih belum tuntas dengan KKM 75. Dari 4 responden belum mencapai kriteria ketuntasan minimal (KKM) yaitu 75. Pembelajaran tuntas apabila siswa memperoleh nilai $\geq 75$ (KKM). Nilai PTS selanjutnya dijadikan peneliti sebagai nilai prasiklus. Penelitian ini dilakukan dalam 2 siklus, siklus 1 dan siklus 2 .

\section{Hasil Penelitian Siklus I}

Hasil pengamatan keterampilan guru pada siklus I pertemuan I dan II jumlah skor rata-rata keterampilan guru dalam mengelola kegiatan pembelajaran membaca puisi mata pelajaran Bahasa Indonesia menggunakan model think pair share pada siklus I pertemuan 1 memperoleh persentase $70 \%$ dengan kriteria cukup. Hal ini ditunjukkan dari 10 indikator yang diamati. 
Dwi Ratna Khoirun Naza, Nur Fajrie, Sri Utaminingsih

Peningkatan Keterampilan Berkomunikasi Anak SD Menggunakan Model Think Pair Share........... Jurnal Prasati Ilmu. Volume 1 Nomor 3 Hlm 28-35

Penilaian hasil pengamatan keterampilan guru dalam mengelola kegiatan pembelajaran pada siklus I pertemuan 2 masih cukup berkembang dengan baik karena naik $4 \%$. Berdasarkan tabel 4.5, dapat dilihat bahwa jumlah skor rata-rata keterampilan guru dalam mengelola kegiatan melatih keterampilan berkomunikasi mata pelajaran Bahasa Indonesia dan IPS menggunakan model Think Pair Share.

Hasil pengamatan aktivitas belajar siswa dalam kegiatan pembelajaran untuk mengembangkan komunikasi dalam pembelajaran tematik menggunakan model think pair share menunjukkan bahwa siswa pada siklus I pertemuan I masih cenderung malu dan diam ketika proses pembelajaran dilakukan. Apabila diminta untuk mengutarakan pendapatnya atau diskusi siswa enggan dengan alasan malas. Sedangkan di pertemuan II siklus I terdapat peningkatan perilaku. Siswa mulai mau aktif dan terlibat dalam proses pembelajaran dan berani mengemukakan pendapatnya.

Keberhasilan penelitian ini diukur dengan tercapainya indikator keberhasilan penelitian, salah satunya adalah keterampilan berkomunikasi pembelajaran tematik melalui model think pair share sebanyak 50\% siswa mendapatkan nilai di atas KKM. Berdasarkan data yang telah diperoleh pada siklus I, siswa yang telah mencapai KKM sebanyak 2 siswa sedangkan yang belum mencapai KKM sebanyak 2 siswa. Persentase ketuntasan klasikal siklus I yaitu $50 \%$.

Ketuntasan klasikal siklus I sebesar 50\% menunjukkan bahwa penelitian pada siklus I masih perlu ditingkatkan. Namun keterampilan membaca puisi siswa dari prasiklus ke siklus I sudah terlihat ada peningkatan. Berikut tabel keterampilan berkomunikasi siswa prasiklus ke siklus I.

Tabel 2 Peningkatan Keterampilan Berkomunikasi Siswa

\begin{tabular}{|c|c|c|c|c|c|}
\hline \multirow{2}{*}{$\begin{array}{c}\text { Nila } \\
\text { i }\end{array}$} & \multirow{2}{*}{$\begin{array}{c}\text { Ketera } \\
\text { ngan }\end{array}$} & $\begin{array}{c}\text { Jumlah } \\
\text { Siswa }\end{array}$ & $\begin{array}{c}\text { Pers } \\
\text { enta } \\
\text { se }\end{array}$ & $\begin{array}{c}\text { Juml } \\
\text { ah } \\
\text { Siswa }\end{array}$ & $\begin{array}{c}\text { Persent } \\
\text { ase }\end{array}$ \\
\hline$\geq 75$ & Tuntas & 0 & $0 \%$ & 2 & $50 \%$ \\
\hline$<75$ & $\begin{array}{c}\text { Tidak } \\
\text { Tuntas }\end{array}$ & 4 & $\begin{array}{c}100 \\
\%\end{array}$ & 2 & $50 \%$ \\
\hline \multicolumn{2}{|c|}{ Jumlah } & 4 & $\begin{array}{c}100 \\
\%\end{array}$ & 4 & $100 \%$ \\
\hline
\end{tabular}

Sumber: Data Primer Peneliti (Hasil Tes Prasiklus dan Evaluasi Siklus I)

\section{Hasil Penelitian Siklus II}

Siklus II terdiri dari 2 pertemuan. Materi yang diberikan adalah membaca puisi anak dengan lafal dan intonasi yang tepat. Kompetensi dasar: IPS. Mengidentifikasi kegiatan ekonomi dan hubungannya dengan berbagai bidang pekerjaan serta kehidupan sosial dan budaya di lingkungan sekitar sampai provinsi. Menyajikan hasil identifikasi kegiatan ekonomi dan hubungannya dengan berbagai bidang pekerjaan, serta kehidupan sosial dan budaya di lingkungan sekitar sampai provinsi. Bahasa Indonesia. Mencermati tokok-tokoh yang terdapat pada teks fiksi. Menyampaikan hasil identifikasi tokohtokoh yang terdapat pada teks fiksi secara lisan, tulis, dan visual. Membandingkan watak setiap tokoh pada teks fiksi. Menyajikan hasil membandingkan watak setiap tokoh pada teks fiksi secara lisan, tulis dan visual.

Jumlah skor rata-rata keterampilan guru dalam mengelola kegiatan pembelajaran membaca puisi mata pelajaran Bahasa Indonesia menggunakan model think pair share pada siklus II pertemuan 1 memperoleh persentase $78 \%$, sedangkan pada pertemuan II memperoleh presentase $86 \%$. Rata rata mencapai $82 \%$ dengan kriteria baik. Penilaian hasil pengamatan keterampilan guru dalam mengelola kegiatan pembelajaran pada siklus I pertemuan 2 masih cukup berkembang dengan baik karena naik $8 \%$, artinya 2 kali lipat dari kenaikan sebelumnya.

Observasi aktivitas belajar siswa dalam penelitian ini dilakukan oleh peneliti sendiri. Pengamatan ini dilakukan untuk mengamati aktivitas belajar siswa dalam keterampilan berkomunikasi yang dilaksanakan oleh peneliti. Tahapan penelitian ini adalah observer diberikan lembar observasi aktivitas siswa sebelum pembelajaran kemudian observer memasuki kelas dan mengamati aktivitas belajar siswa pada saat proses pembelajaran berlangsung.

Hasil pengamatan aktivitas belajar siswa dalam keterampilan berkomunikasi dalam pelajaran tematik menggunakan model think pair share, menunjukkan bahwa dari siklus II pertemuan I ke pertemuan II terdapat peningkatan karakter belajar siswa, khususnya keterampilan berkomunikasi. Siswa lebih berani dan siap dengan materi pelajaran yang disampaikan oleh guru. Hal tersebut dapat dilihat secara detail pada table berikut ini. 
Dwi Ratna Khoirun Naza, Nur Fajrie, Sri Utaminingsih

Peningkatan Keterampilan Berkomunikasi Anak SD Menggunakan Model Think Pair Share........... Jurnal Prasati Ilmu . Volume 1 Nomor 3 Hlm 28-35

Tabel Hasil pengamatan Aktivitas Belajar Siswa

\begin{tabular}{|c|c|c|c|c|c|c|}
\hline \multirow[b]{2}{*}{ No } & \multirow[b]{2}{*}{ Nama } & \multirow[b]{2}{*}{ KKM } & \multirow{2}{*}{\begin{tabular}{|c|} 
Nilai \\
Prasiklus
\end{tabular}} & \multicolumn{2}{|c|}{ Nilai } & \multirow[t]{2}{*}{ Ket } \\
\hline & & & & $\begin{array}{c}\text { Pertemua } \\
\text { I }\end{array}$ & $\begin{array}{c}\text { Pertemuan } \\
\text { II }\end{array}$ & \\
\hline 1 & AKR & 75 & 71 & 80 & 84 & $\begin{array}{c}\text { Tuntas, } \\
\text { Naik }\end{array}$ \\
\hline 2 & BDR & 75 & 72 & 85 & 89 & $\begin{array}{c}\text { Tuntas, } \\
\text { Naik }\end{array}$ \\
\hline 3 & IAZ & 75 & 73 & 83 & 89 & $\begin{array}{c}\text { Tuntas, } \\
\text { Naik }\end{array}$ \\
\hline 4 & IK & 75 & 72 & 81 & 85 & $\begin{array}{c}\text { Tuntas, } \\
\text { Naik }\end{array}$ \\
\hline
\end{tabular}

Sumber: Data Primer Peneliti (Hasil Tes Prasiklus dan Evaluasi Siklus II)

Berdasarkan tabel tersebut dapat dilihat bahwa siswa yang telah mengikut model pembelajaran think pair share dengan berbantuan media ular tangga untuk meningkatkan keterampilan berkomunikasi siswa cukup berhasil. Dapat dilihat bahwa nilai yang didapatkan pada siklus ke II ini berbeda jauh dengan nilai sebelumnya. Jika pada prasiklus keempat siswa tidak tuntas, di siklus II ini nilai masing masing siswa bertambah cukup signifikan. Ketuntasan nilai siswa pada siklus II ini $100 \%$ dan siswa memiliki nilai diatas KKM, yaitu 75. Model Think Pair Share sangat berpengaruh pada keterampilan berkomunikasi siswa kelas IV, seperti penelitian yang dilakukan oleh Rianingsih, Mawardi, dan Wardani, (2020) bahwa keterampilan komunikasi kelas 3 di SD Ledok 05 Salatigan terdapat peningkatan yang cukup signifikan dengan menggunakan model Think Pair Share.

Konsep pembelajaran Penelitian yang dilakukan oleh peneliti berbeda dengan penelitian yang dilakukan oleh Rusiyono (2011) bahwa keterampilan berkomunkasi dinilai dengan model pembelajaran project, akan tetapi pada penelitian ini menggunakan model Think Pare Share dan dengan bantuan media ular tangga. Menurut peneliti, suatu pembelajaran akan efektif ketika diterapkan dengan model dan disertai dengan media pembelajaran yang menarik, seperti ular tangga. Sedangkan menurut Afandi (2015), media ular tangga digunakan untuk meningkatkan motivasi belajar siswa. Sedangkan dalam penelitan ini media ular tangga digunakan untuk meningkatkan keterampilan berkomunikasi siswa. Pada penelitian ini model penelitian yang digunakan cukup berbeda dengan penelitian peneltian sebelumnya, yaitu mix method. Selain itu, peneltian ini dilaksanakan masa pandemi Covid-19. Hal ini membuat desain penelitan disesuaikan dengan yang dilaksanakan setiap sekolah.

Dengan demikian dapat kita simpulkan bahwa pelaksanaan pembelajaran dengan model think pair share dalam meningkatkan keterampilan berkomunikasi siswa dalam belajar tematik berbantuan media ular tangga dapat dikatakan cukup berhasil yang ditunjukkan dengan meningkatnya nilai yang diperoleh siswa. Hal tersebut selaras dengan penelitian yang dilakukan oleh Simbolon (2017) bahwa penerapan model Think Pair Share di kelas VI SD dapat meningkatkan hasil belajar siswa. Hasil tersebut dapat diketahui dari peningkatan persentase ketuntasan belajar siswa pada pra siklus $(68,57 \%)$, siklus I $(77,14 \%)$, dan siklus II $(91,42 \%)$.

\section{SIMPULAN}

1. Peningkatan aktivitas belajar siswa dalam pembelajaran IPS pada tema 8 daerah tempat tinggalku subtema 3 melalui model Think Pare Share berbantuan media ular tangga. Kenaikan aktivitas belajar siswa dari $0 \%$ menjadi $50 \%$ dan pada siklus kedua menjadi $100 \%$.

2. Peningkatan keterampilan berkomunikasi siswa dalam pembelajaran IPS pada tema 8 daerah tempat tinggalku subtema 3 melalui model Think Pare Share berbantuan media ular tangga. Hal ini ditunjukkan dengan siswa yang berani dalam mengutarakan pendapatnya ketika bermain ular tangga.

\section{DAFTAR PUSTAKA}

Afandi, Rifki. 2015. Pengembangan Media Pembelajaran Permainan Ular Tangga Untuk Meningkatkan Motivasi Belajar Siswa Dan Hasil Belajar IPS Di Sekolah Dasar. Jurnal Inovasi Pembelajaran. 1 (1): 77-90.

Arikunto, Suharsimi. 2012. Penelitian Tindakan Kelas. Jakarta: PT Bumi Aksara.

Arsyad, Azhar. 2013. Media Pembelajaran. Jakarta: Rajagrafindo.

Creswell, John W. (2007) Qualitative Inquiry \& Research Design choosing Among Five Approaches. Calfornia: Sage Publiation Inc.

Fardani, Much Arsyad, dkk. 2021. Game Panjol Berbasis Android untuk Meningkatkan Karakter Bersahabat pada Siswa Sekolah Dasar. Refleksi Edukatika: Jurnal Ilmiah Kependidikan, 11 (2): 241-249.

Hamruni. 2012. Strategi Pembelajaran. Yogyakarta: Insan Madani.

Hendrikus, Dori Wuwur. 1991. Retorika Terampil Berpidato, Berdiskusi, Beragumentasi, Bernegosiasi. Yogyakarta: Kanisius. 
Huda, Miftahul. 2013. Model-Model Pengajaran dan Pembelajaran. Yogyakarta: Pustaka Pelajar.

Isnarto, Abdurrrahman, Sugianto. 2017. Pengembangan Laboratorium Media Pembelajaran Berbasis Kebutuhan Sekolah. Jurnal Profesi Keguruan. 3 (2): 244-252.

Moningka, Marsuri Juningsi dan Meilane Sahetapy. 2019. Penerapan Metode Think Pair Share untuk Meningkatkan Kerja Sama Siswa Kelas VII pada Mata Pelajaran IPA Terpadu. Bio-Pedagogi: Jurnal Pembelajaran Biologi. 8 (2): 72-76.

Nikmah, Nurul. Rahayu, Ratri, dan Fajrie Nur. 2020. Penerapan Media Pembelajaran Math Mobile Learning untuk Meningkatkan Kemampuan Pemecahan Masalah Siswa Kelas IV. Wasis: Jurnal Ilmiah Pendidikan, 1(2): 1-8.

Nurazizah, Khikmah Fitriani dan Wuri Wuryandari. 2019. Pengaruh Model Kooperatif Tipe Think Pair Share terhadap Kerjasama Siswa. Jurnal Civics: Media Kajian Kewarganegaraan. 16 (1): 80-88.

Nurgiantoro, Burhan. 2001. Penilaian dalam Pembelajaran Bahasa dan Sastra Yogyakarta: BPFE.

Rianingsih, Dewi. Mawardi, dan Krisma Widi Wardani. 2020. Penerapan Model Pembelajaran TPS (Think Pair Share) dalam Rangka Meningkatkan Keterampilan Komunikasi Siswa Kelas 3. Naturalistic: Jurnal Kajian Penelitian dan Pendidikan dan Pembelajaran. 3 (2): 339-346.

Rumono, Henny Novita. Djoko Setyabudi, dan Tandiyo Pradekso. 2014. Hubungan Intensitas Komunikasi Orangtua-Anak dan Kelompok Referensi dengan Minat Memilih Jurusan Ilmu Komunikasi Pada Siswa Kelas XII. Jurnal Ilmu Komunikasi. 5 (7): 78-83.

Saidah, Noor. 2015. Peningkatan Hasil Belajar Matematika Materi Segitiga dan Jajargenjang Melalui Pembelajaran Think Pair Share (TPS) Berbantuan CD Pembelajaran pada Siswa Kelas IV SDN 4 Puyoh Kecamatan Dawe Kabupaten Kudus Semester 1 Tahun Pelajaran 2014/2015. Refleksi Edukatika: Jurnal Ilmiah Kependidikan, 5 (2): 1-10.

Setiawan, Andri, Henry Praherdhino dan Sulthoni. 2019. Penggunaan Game Edukasi Digital Sebagai Sarana Pembelajaran Anak Usia Dini. Jurnal Inovasi Teknologi Pembelajaran: Kajian dan Riset dalam Teknologi Pembelajaran. 6 (1): 39-44.
Simbolon, Usdin. 2017. Penerapan Metode Think Pair Share dalam meningkatkan hasil Belajar Siswa Mata Pelajaran Bahasa Indonesia Kelas VI SD 166492 Tebing Tinggi. ESJ. 7 (3). 430-439.

Sugiyono. 2013. Metode Penelitian Pendidikan: Pendekatan Kuantitatif, Kualitatif, dan $R \& D$. Bandung: Alfabeta.

Tarigan, Henry Guntur. 2008. Berbicara Sebagai Suatu Keterampilan Berbahasa. Bandung: Angkasa.

Trianto. 2010. Model Pembelajaran Terpadu: Konsep, Strategi, dan Implementasinya dalam Kurikulum Tingkat Satuan Pendidikan (KTSP). Jakarta: Bumi Aksara.

Warno Edy Supomo. 2018. Pengaruh Model Think Pair Share untuk Meningkatkan Motivasi Belajar Siswa Dalam Pembelajaran Pendidikan Kewarganegaraan di Kelas VII SMP Kartika IV 8 Malang Tahun Pelajaran 2017/2018. Jurnal Ilmiah Fakultas Keguruan dan Ilmu Pendidikan 19 (1): 8999. 